DOI: $10.4274 /$ tod. 81894

Turk J Osteoporos 2018;24:29-31

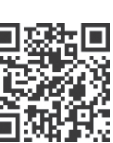

\title{
Traumatic Tetraplegia without Radiologic Abnormalities in an Elderly Woman: A Case Report
}

\author{
Yaşlı Bir Kadında Radyolojik Anormalliklerin Eşlik Etmediği Travmatik Tetrapleji: \\ Olgu Sunumu
}

(D) Senem Şaş, (D) Şeyda Toprak Çelenay*

Ahi Evran University Training and Research Hospital, Clinic of Physical Medicine and Rehabilitation, Kırşehir, Turkey *Ankara Yıldırım Beyazıt University Faculty of Health Sciences, Department of Physiotherapy and Rehabilitation, Ankara, Turkey

\section{Abstract}

Spinal cord injury without radiologic abnormality (SCIWORA), which is not accompanied by radiographic abnormalities, implies literally a specific type of spinal cord injury. In most cases, spinal cord injuries can be detected by magnetic resonance imaging (MRI). In this report, we present an atypical case of tetraplegic spinal cord injury in an elderly woman with SCIWORA. A 73-year-old female tetraplegic patient underwent MRI, and no specific lesions were found in any segments of the spinal cord. Furthermore, the patient had paralysis and pathological reflexes at four extremities. Below the C7 dermatome level hypoesthesia was determined. A 6-week physical therapy and rehabilitation program was performed. After the program, it was observed that spasticity decreased, sitting balance increased and the patient could use wheel-chair. Keywords: Spinal cord injury, trauma, tetraplegia, physical therapy and rehabilitation

\section{$\ddot{O z}$}

Radyografik anormalliklerin eşlik etmediği spinal kord yaralanması (SCIWORA) kelimenin tam anlamılla spinal kord hasarının spesifik bir tipini belirtir. Çoğu olguda omurilik yaralanmaları manyetik rezonans görüntüleme (MRG) ile tespit edilebilir. Bu yazıda, SCIWORA'lı yaşlı bir kadında tetraplejik omurilik hasarının geliştiği atipik bir olgu sunulmaktadır. Yetmiş üç yaşındaki tetraplejik bir kadın hastadan MRG çekildi ve spinal kordun herhangi bir bölümünde spesifik bir lezyon bulunamadı. Öte yandan, hastanın dört ekstremitede paralizisi ve patolojik refleksleri mevcuttu. C7 dermatom seviyesinin altında hipoestezi tespit edildi. Altı haftalık bir fizik tedavi ve rehabilitasyon programı gerçekleştirildi. Program sonrasında, spastisitenin azaldığı, oturma dengesinin arttı̆̆ı ve hasta tekerlekli sandalyeyi kullanabileceği gözlendi.

Anahtar kelimeler: Spinal kord yaralanması, travma, tetrapleji, fizik tedavi ve rehabilitasyon

\section{Introduction}

Spinal cord injury without radiologic abnormality (SCIWORA) was firstly described in 1982 by Pang and Wilberger (1). They used the terminology to define the cases of spinal cord injury that had no sign of vertebral fractures or malalignment on radiographs or computerized tomography (CT). Magnetic resonance imaging (MRI) is preferred over $\mathrm{CT}$ in radiological diagnosis of spinal cord injury because of its sensitivity to soft tissue than that of CT. Therefore, the scope of SCIWORA is currently narrowed, and SCIWORA is exceptionally uncommon $(2,3)$.

SCIWORA, a clinical-radiological condition, is commonly seen in children and its recorded incidence ranges from $4 \%$ to $66 \%$ (2-4). SCIWORA is rarely seen in adults, and mostly cervical spine and much less frequently thoracic or lumbar spines are involved in these patients (5). In addition, treatment protocol in SCIWORA varies, such as immobilization of spine with collar, bed rest, methylprednisolone, physical therapy and rehabilitation, and surgical procedures (6).

Most SCIWORA cases are pediatric (7). Cervical spine is the most common region in SCIWORA (5). However, Khatri et al. (8) reported a 40 year-old man with the neurological level thoracic 12. In this study, we present a patient with tetraplegic SCIWORA in an elderly woman, although many cases are pediatric or adult.

\section{Case Report}

A 73-year-old woman applied with tetraplegia following a traffic accident. As a result of the accident, multiple costal fractures and hemothorax occurred. The case was hospitalized in the

Address for Correspondence/Yazıșma Adresi: Senem Şaş MD, Ahi Evran University Training and Research Hospital, Clinic of Physical Medicine and Rehabilitation, Kırşehir, Turkey Phone: +90 5055520451 E-mail: senemsas@gmail.com ORCID ID: orcid.org/0000-0002-5616-5723 Received/Geliş Tarihi: 01.03.2017 Accepted/Kabul Tarihi: 28.05.2018

${ }^{\circ}$ Copyright 2018 by the Turkish Osteoporosis Society Turkish Journal Of Osteoporosis published by Publishing House. 
intensive care unit. The patient consulted in the intensive care unit because of paralysis in upper and lower extremities. There was no history of loss of conscious, seizures, vomiting, or previous neurological disorder. No abnormal laboratory results were observed. The patient underwent cranial and cervical MRI. Also, no significant abnormalities, other than herniated discs were observed (Figure 1).

We performed manual muscle tests according to accepted norms. The upper extremity muscle strength from C5 to C6 was 5/5, C7 was 4/5, C8-T1 was $1 / 5$, and the lower extremity muscle strength (L2-S1) was grade 1/5. Hypoesthesia below the $\mathrm{C7}$ dermatome level was described. No abnormality in anal sensation was observed. The neurological level was at $C 7$ level and American Spinal Injury Association grade was B. Pathologic reflexes were presented. The symptoms of neurogenic bladder and bowel were also examined in the patient.

In clinical examination behind one week, grade 2 spasticity in achilles and hip abductors according to the Ashworth scale were observed. After two weeks in our inpatient clinic, the patient presented autonomic dysreflexia (AD) with 160/90 blood pressure due to fecal impaction. Although the routine use of laxatives is encouraged, nifedipine $30 \mathrm{mg}$ was recommended. No abnormalities in blood pressure were observed after an AD attack. No urodynamic study could be performed because of the unwillingness of the patient. Bladder was emptied by foley catheter. During follow-up, after three weeks in our patient, spasticity increased, and hip adductors, knee extensors, and achilles in both limbs were grade 3 according to the Ashworth scale.

The physical therapy and rehabilitation program was carried out 5 days a week for six weeks by a physical therapist. Each session took 40 to 45 minutes. The program consisted of exercises

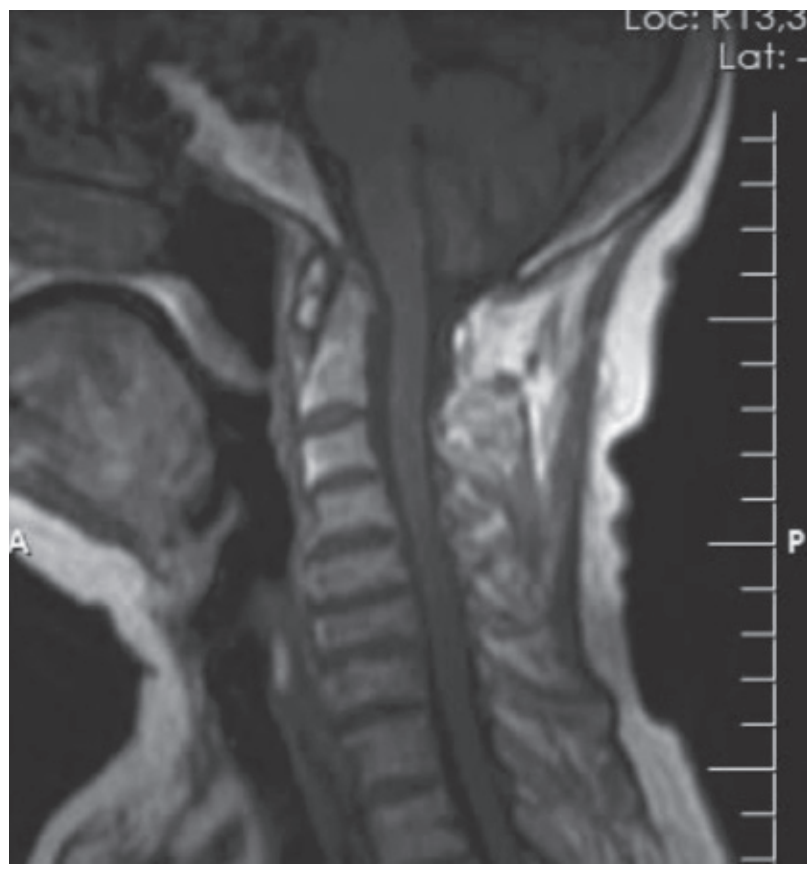

Figure 1. Multilevel disc degeneration in bed, mat activities, balance training in sitting position, and breathing exercises. The active range of motion for headneck and upper extremities, the passive range of motion for lower extremities, stretching exercises for spastic muscles were performed. Any medical treatments were not used for spasticity. The patient couldn't tolerate therapeutic ambulation. Afterthe program, it was observed that spastisity decreased to grade 2 level, sitting balance increased, and the patient could use wheelchair. The consent approval of the patient was received.

\section{Discussion}

SCIWORA is responsible for about $1-9 \%$ of all spinal cord injuries. In pediatric cases it varies between $13 \%$ and $42 \%$ (7). Cervical involvement is the most prevalent region in SCIWORA (5). Furthermore, it has been reported a 40 year-old man with the neurological level thoracic 12 (8). In this study, we present a senile SCIWORA case, although many cases are pediatric or adult.

Pang identified four mechanisms in SCIWORA, namely, flexion, hyperextension, longitudinal distraction, and ischemia (1). In the adult population any cases have pre-existing spondylosis changes (2).

It has been reported senile cases with spondylosis had spurs in the posterior region of the vertebra. Besides, in elderly 120 cases, ligamentum flavum may cause bulging due to decreased body weight. On the other hand, hyperextension injury may lead Central cord syndrome (9). In the present case hyperextension injury may lead spinal cord injury.

Besides, cervical spondylosis leads to spinal cord injury $(10,11)$ degenerative changes in spine in the present case may have led to tetraplegia. In this case, we think that spinal cord injury is caused by degenerative changes.

In SCIWORA cases, good prognostic factors are presented as early diagnosis, adolescent age, and edema in spinal cord without hemorrhage or infarction, early stabilization of vertebral column $(12,13)$.

Conventional radiographs and $C T$ have been recommended in the diagnosis of SCIWORA. MRI helps identify spinal cord parenchymal abnormalities and ligamentous disruptions. Cord concussion, edema, contusion, and transection are the forms of parenchymal cord injuries $(8,10)$. The presented case had poorer prognosis despite normal MRI findings except herniated discs and degenerative changes. And also, senility may be important in prognosis of SCIWORA.

It was recommended different methods for the diagnosis of SCIWORA, a clinical-radiological condition. It has been suggested diffusion weighted MRI sequences in the Somatosensory Evoked Potentials (SSEP), positron emission tomography (PET) imaging can be used in spinal cord pathologies (13-15). We used clinical findings in the diagnosis of SCIWORA. Our limitation in the present study is that we did not perform SSEP, PET, urodynamics, and electromyography.

On the other hand, there are various treatment protocols in SCIWORA $(1,2)$. Early mobilization of cases and a 
multidisciplinary team may facilitate maintenance and advance long period results. Medicines such as methylprednisolone and rehabilitation procedures present demanding outcomes of neurological improvement in some cases (6). We performed a 6-week rehabilitation program. However, the prognosis of our case is not as good as the ones reported in the literature, because she was elderly and experienced AD. However, after the rehabilitation program, in our case, spastisity decreased, sitting balance increased and our case could ambulate with wheel chair.

In conclusion, SCIWORA in the elderly can show poorer prognosis. Early diagnosis of SCIWORA can result in good outcomes. Immobilization of spinal cord early is vital until the evaluation of neurodeficit and radiography. However, the physical therapy and rehabilitation applications of SCIWORA may lead to improving various functional parameters.

\section{Ethics}

Informed Consent: The patient aaproval was received.

Peer-review: Externally and internally peer-reviewed.

\section{Authorship Contributions}

Surgical and Medical Practices: S.Ş., Ş.T.Ç., Concept: S.Ş., Design: S.Ş., Ş.T.Ç., Analysis or Interpretation: S.Ş., Literature Search: S.Ş., Writing: S.Ş.

Conflict of Interest: No conflict of interest was declared by the authors.

Financial Disclosure: The authors declared that this study received no financial support.

\section{References}

1. Pang D, Wilberger JE Jr. Spinal cord injury without radiographic abnormalities in children. J Neurosurg 1982;57:114-29.

2. Tewari MK, Gifti DS, Singh P, Khosla VK, Mathuriya SN, Gupta SK, et al. Diagnosis and prognostication of adult spinal cord injury without radiographic abnormality using magnetic resonance imaging: analysis of 40 patients. Surg Neurol 2005;63:204-9.

3. Boese CK, Lechler P. Spinal cord injury without radiologic abnormalities in adults: a systematic review. J Trauma Acute Care Surg 2013;75:320-30.

4. Choi JU, Hoffman HJ, Hendrick EB, Humphreys RP, Keith WS. Traumatic infarction of the spinal cord in children. J Neurosurg 1986;65:608-10.

5. Hill SA, Miller CA, Kosnik EJ, Hunt WE. Pediatric neck injuries. A clinical study. J Neurosurg 1984;60:700-6.

6. Rozzelle CJ, Aarabi B, Dhall SS, Gelb DE, Hurlbert RJ, Ryken TC, et al. Spinal Cord Injury Without Radiographic Abnormality (SCIWORA). Neurosurgery 2013;72:227-33.

7. Ruge JR, Sinson GP, McLone DG, Cerullo LJ. Pediatric spinal injury: the very young. J Neurosurg 1988;68:25-30.

8. Khatri K, Farooque K, Gupta A, Sharma V. Spinal cord injury without radiographic abnormality in adult thoracic trauma. Arch Trauma Res 2014 25(3): e19036. DOI: 10.5812/atr.19036.

9. Kasimatis GB, Panagiotopoulos E, Megas P, Matzaroglou C, Gliatis J, Tyllianakis $M$, et al. The adult spinal cord injury without radiographic abnormalities syndrome: magnetic resonance imaging and clinical findings in adults with spinal cord injuries having normal radiographs and computed tomography studies. J Trauma 2008;65:86-93.

10. Knox J. Epidemiology of spinal cord injury without radiographic abnormality in children: a nationwide perspective. J Child Orthop 2016;10:255-60.

11. Sharma $S$, Singh $M$, Wani $I H$, Sharma $S$, Sharma $N$, Singh $D$. Adult Spinal Cord Injury without Radiographic Abnormalities (SCIWORA): Clinical and Radiological Correlations. J Clin Med Res 2009;3:165-72.

12. Buyukbebeci O, Bilge O, Karsli B, Kacira BK, Kutahya H, Mustafa IA. Spinal Cord Injury Without Radiological Abnormality (SCIWORA): Is It Still a Notable Definition? Journal of Spine 2015:4:215

13. Shen $H$, Tang $Y$, Huang $L$, Yang $R$, Wu $Y$, Wang $P$, et al. Applications of diffusion-weighted MRI in thoracic spinal cord injury without radiographic abnormality. Int Orthop 2007;31:37583.

14. Pang D. Spinal cord injury without radiographic abnormality in children, 2 decades later. Neurosurgery 2004;55:1325-42.

15. Kamoto Y, Sadato N, Yonekura Y, Tsuchida T, Uematsu H, Waki $A$, et al. Visualization of the cervical spinal cord with FDG and high-resolution PET. J Comput Assist Tomogr 1998;22:487-91. 